Article

\title{
Paradoxes and Possibilities for a 'Green' Housing Sector: A Swedish Case
}

\author{
Pernilla Hagbert $^{1, *}$, Mikael Mangold ${ }^{2}$ and Paula Femenías ${ }^{1}$ \\ 1 Department of Architecture, Chalmers University of Technology, Göteborg 41296, Sweden; \\ E-Mail: paula.femenias@chalmers.se \\ 2 Department of Civil and Environmental Engineering, Chalmers University of Technology, \\ Göteborg 41296, Sweden; E-Mail: mikael.mangold@chalmers \\ * Author to whom correspondence should be addressed; E-Mail: hagbert@chalmers.se; \\ Tel.: +46-736-277-220.
}

Received: 1 March 2013; in revised form: 3 April 2013 / Accepted: 25 April 2013 /

Published: 6 May 2013

\begin{abstract}
As global and local visions for sustainable living environments are increasingly supported by policies and concrete practices in construction, the building and housing sector is seeking to mitigate its environmental impact as well as assume a greater social responsibility. The overarching policy objectives set to concretize what a sustainable housing development entails, however, tend to rely on equivocal terminology, allowing a varied interpretation by key industry practitioners. Though in line with an ecological modernization paradigm in policy, the promotion of a market-driven environmentalism in housing faces multiple challenges as varying interests and perspectives collide. Supported by empirical findings of a semi-structured interview study conducted with housing developers in a new 'green' urban district in Göteborg, Sweden, theoretical frameworks surrounding the paradoxical path towards a sustainable housing development are presented. Inconsistencies between outspoken ambitions; social dimensions; and the framing of efficiency in new housing are discussed. Possibilities for the housing sector are given in the recognition of new forms of development, where a systemic perspective is required in the alignment between how industry, policy and the market perceives housing development and what is actually sustainable.
\end{abstract}

Keywords: sustainable development; housing; building sector; developers; equivocal terminologies; social capital 


\section{Introduction}

The concept of sustainable development has come to encompass various interpretations, ranging from political discourse to pragmatic approaches regarding how to meet the challenges of global development within what progressively is understood as finite ecological limits. On both a local and global level, the establishment of visions and targets for environmental or societal governance effects and relies on all sectors to outline and facilitate measures to reach these goals. The building sector-and the myriad of supporting sectors connected to it - is a main contributor to the environmental stress and resource depletion of modern society [1,2]. Conversely, major social and financial implications of the built environment should also be considered, as playing a key part in human development and economic growth [2].

Aims and policies for an environmentally and socially considerate urban (re)development bring focus not only to material values and financial indicators, but also the complexity of regulating a holistic sustainable development within a current market paradigm, as seen in a Northern European as well as global context [3-9]. With a lack of regulatory precision and clear national policy support, responsibility is shifted to the building sector. This paper addresses the question whether the sector, with the focus on a developer perspective, can be expected to pursue a holistic agenda and deliver sustainable living environments accordingly.

With an increased urbanization putting further demand on the creation of new urban living environments, the push towards greening housing development in particular can be seen in an emerging interest and increasing demand for 'green' certified or labeled buildings [10,11]. This is illustrated in the development of new 'green' urban districts in metropolitan growth regions around Europe. An acute housing shortage, as in the Swedish context, along with a subdued investment capacity due to the recent recession, is seen as a direct impediment to further development-a situation similar to that of many growing urban regions around the world.

Since the latter part of the last decade, sustainability has increasingly been part of the general agenda in the Swedish building sector [12,13]. This development is mainly driven by anticipated regulation for European Energy Performance, along with national energy/environmental goals, and local environmental policies in metropolitan areas. It is further supported also on a global scale by an increased competence for these issues within the sector, a push for certification systems, and the formulation of green strategies among housing developers around the world, as a response to a growing market for such competitive distinction both nationally and internationally [14]. However, while energy efficiency, and in part environmental preferences regarding material choices are considered, the social dimension of sustainability as well as other impacts of the built environment on ecological systems is still overlooked $[3,15]$.

Particularly the discourse on 'sustainable housing' indicates a belief in the creation of living environments with a lower impact on global climate change [16]. The overarching objectives set to concretize what a sustainable development entails however tend to rely on rather equivocal terminology [17]. This imprecision allows varied interpretations to be made by industry practitioners, and subsequently constitute a potential challenge in implementation, which is addressed in this paper.

The pursuit of a societal and humanistic development within ecological limits is stated in parallel to aims calling for and stimulating economic growth, outlining the paradoxes of contemporary 
discourse [18,19]. Although in line with an ecological modernization paradigm [20,21], the promotion of a market-driven environmentalism to achieve eco-innovation in housing is, as is discussed in this paper, lined with obstacles as differing interests and perspectives collide. The housing sector needs to cater to a plethora of demands from policy, clients, and investors, of which some are indeed of an environmental or social nature. However, the range in these demands poses a restriction in the possibility to take a more holistic perspective on what is built.

Contributing to a discussion on the interpretative difficulties, and thereby in parts paradoxical development of a sustainable housing sector, the aim is here to highlight the discourse from a developer and residential development perspective. The paper begins with a background to the sustainable development discourse. This is followed by a theoretical elaboration on the current framing of environmental sustenance and economical understanding of housing development. Empirical material is presented in the form of findings from semi-structured interviews with developers in the case of a currently redeveloped urban area in Göteborg, Sweden. Main aspects are outlined: the assumption of an economical and political system in place; a restricted perspective on sustainability in housing; and the role of the resident. The material is used to highlight paradoxes that arise in the usage of sustainable development as a term in the building sector. The paper is concluded with a reflection on the implications and possibilities of this, pointing towards ways forward. Developing both policy and practice, as well as emphasizing collaboration for a more holistic discourse, is proposed.

\section{Theoretical Background}

\subsection{Defining Sustainable Development in the Housing Sector}

The complex linkages between resource depletion, climate change and societal development are increasingly acknowledged and discussed as global challenges. Mid and late 20th century preservationist movements based a growing concern for the environmental impact of human endeavors in an ecocentric and "deep green" advocacy, also notable in early sustainable housing projects [12]. With the dimension of a post-colonial global understanding - calling for an equal opportunity for societal development - the discourse in the global community evolved towards a definition of how to sustain such a development. Recent discourse, on the other hand, has focused on merging a contemporary growth paradigm with environmental preservation or regeneration and societal prosperity within the term "green economy" [22] (evident also at the Rio+20 earth summit [23]). In the building sector a green growth is proposed primarily through, but not limited to, strategic development within expanding urban areas, streamlined building and planning processes, and by the strengthening of an emerging market for eco-efficient industry strategies, services and clean-tech products.

In sustainability sciences, it is common to start in epistemology and the definitions of sustainable development. Kates et al. [24] define development targets to be, among others: equity, equal opportunity, wealth, the productive sector, consumption and social capital; meanwhile sustaining resources, the environment, places and cultures. These are relevant dimensions in reference to the study presented here. The definitions are used to point to the challenges, but also the possibilities in the transition towards a sustainable housing development. One such paradox that applies on a general, as well as sector specific scale, is the inconsistency of sustaining life support resources while developing 
consumption, if developing is synonymous with increasing [25]. Other sustainability definitions present relevant targets for the building sector, as it is a large contributor to the development of productive sectors. The sector could also take a more active role in developing equity and equal opportunity in the housing market, as well as the creation of social capital, if given opportunity [3].

There is, however, a risk that the ability of the housing sector to produce a more holistically sustainable and resilient built environment is overlooked due to unilateral interpretations of the above outlined definitions. It could further be restricted by short-term goals given by imprecise public opinion and fluctuations within the economic system. Long term economic development and resilience is equally difficult to pursue in a current growth paradigm, with a recognized correlation between inflated real-estate markets and economic turns [26]. Critics of growth-based sustainable development further argue that efficiency and technology alone are not enough to solve present and upcoming challenges for ecological preservation [18,19,22,25]. These are key aspects to investigate in the expansion of a "green" housing sector that acts within, and enforces intrinsically normative practices and structures.

\subsection{Housing Development}

The legislative and political push for development and expansion of living space in Europe in general, and Sweden in particular, during the second half of the 20th century led to higher residential standards per capita both in terms of $\mathrm{m}^{2} /$ person and comfort level (thermal as well as in material terms). Although Sweden early on established a considerably high level of housing standards, the need for improved housing conditions throughout Europe remains a challenge [27]. This further needs to be put into relation to sustainability in new construction and a deteriorating existing stock. With a general trend of diminishing household size and a normative view on the residential standards expected, the individual need of resources remains. Combined with an increased share of single households, this implies a larger total spatial and material demand compared to households where such functions are shared.

Connecting to strong ideological and normative discourses surrounding spatial, material and infrastructure standards, housing development has been a question for much policy and industry benchmarks over the past century, leading to improvements in general health and environmental quality of residential areas. This raises concerns also on what is appropriate or sustainable, and the distribution of consumption and cost. As evident in housing market fluctuations, the notion of development in this context is nevertheless not solely related to a continued improvement of living environments and conditions, but encompasses a dynamic of speculative properties. Mortgaging structures are an integral part of national and global financial systems [26]. The level of indebtedness in relation to disposable income among households have increased in all the Nordic countries during the last two decades, with rising real and nominal housing prices [28]. Production costs per $\mathrm{m}^{2}$ for apartments in multi-dwelling buildings have simultaneously nearly doubled during the last decade in Sweden [29]. Provision of affordable housing remains a primary issue, and constitutes a main hinderance in the search for equity and equal opportunity in the housing market both on a European and global scale [4,27,30-32]. In a Swedish context, it is important to note that the historic situation has been slightly different than that of other European countries. Subsidies for housing construction and household allowances have been active policy instruments to ensure quality and equality. 
However, the prerequisites for this have changed with shifts in housing policy over the last decades [33]. The urgent shortage in appropriate and affordable housing in metropolitan areas is increasingly recognized as a key issue in sustainable urban development, yet a clear national policy is lacking.

\subsection{Developing a Sustainable Housing Sector}

With global and local visions for the creation of sustainable living environments increasingly supported by policies and concrete practices in construction, the housing sector is seeking to mitigate its environmental impact. Furthermore, private companies are assuming a greater corporate social responsibility, whereas public housing companies are expected to build upon their societal mandate. There is however, as noted above, a gap in the interpretation and hence ambition for sustainable housing. The difficulties that arise in attempting to merge discourses on housing and sustainability are seen in the oftentimes widely differing, sometimes oppositional agendas to be integrated [34].

There are several barriers to the adoption and expansion of green building practices to be found. These can be of an individual as well as organizational or institutional level, involving all actors, and range from limitations in terminology used to regulative obstacles [35]. Going beyond technical solutions is at the same time increasingly viewed as essential, yet remains an important task in an industry perspective where sustainability measures revolve around efficiency [3]. Internalizing externalities in order to reduce household resource consumption, by associating consumption with a price, constitutes a key part of the ecological modernization paradigm [36].

Apart from general concerns about rebound effects of measures focusing primarily on efficiency, a one-sided focus on such parameters can also miss a larger paradigmatic understanding of the impact of the living environments built. This is illustrated in recent findings suggesting that the most significant factor for the leveling out of energy use in Norwegian households during the last two decades is the slower increase in per capita living area, compared to the preceding 20 years [37]. Even though energy-efficiency measures have contributed, the fact that the total living area is not growing at the same rate as population is a main direct explanation. Underlying factors such as demographic changes (including immigration), increased costs or shifting residential preferences are implied.

Pathways towards sustainable development may have been overlooked due to a focus on societal rather than household-scale solutions or behaviors. An important element in developing sustainable practices in a home perspective is to recognize the household not just as units or consumers, but also as active subjects and contributors [38]. If inhabitants are seen as creators of social space, safety networks etcetera, then values are shifted towards facilitating the development of social capital [39].

\section{Materials and Method}

\subsection{A Swedish Case}

The material presented in this paper reflects qualitative findings from an interview study with the seven developers involved in the Kvillebäcken case area in Göteborg, Sweden. The project context constitutes the first phase of a general plan to transform a former central harbor area. As a strategy for the overarching expansion of the center of Göteborg, a model for development - the "Älvstranden model" - has been established in order to reduce financial risks for the city, and thereby distribute 
infrastructure and development costs among the developers involved. Through the formation of a consortium the project is run by a municipally owned development company-responsible for the general plan - in conjunction with developers as well as the municipal planning office.

Common goals were outlined in a consortium treaty, and elaborated on in a program for sustainable development, where Kvillebäcken is framed as a "socially, economically and ecologically sustainable urban district" [40]. The project aims to be a model for sustainable urban residential development, aspiring for Swedish Green Building Council environmental certification level silver, with gold for energy. It is one of the first urban neighborhoods in Göteborg built in line with the municipality's new environmental demands, including strict energy requirements for the 2000 apartments built.

\subsection{Method}

By applying a snapshot casing in the Kvillebäcken development process, perspectives among some main actors in the building sector could be picked up, where questions of sustainability are proposed to be at the forefront $[41,42]$. These perspectives are used to illustrate what key practitioners, in the role as developers, expect, foresee, and overlook in the contemporary sustainable development targets for the housing sector.

The interviewees are respondents as well as informants [43], as the study has a strong inductive emphasis, yet maintains an explicit understanding of sustainable development based in an emerging growth realist perspective [44]. The interviewees give a relevant insight into the particular case, explicitly aiming at being a forerunner for Swedish housing development and thereby relating to similar metropolitan situations around Europe. This case is an illustrative example of an ongoing debate in the global community, although based in a Swedish housing market context.

As part of a larger research project in Kvillebäcken, studies looking at architects' perceptions, as well as insights from differently framed interviews with project managers and property developers are presented elsewhere, but contribute to a greater general understanding of the case. Focusing on the developers' perspective is essential due to the executive role developers are given in the contemporary economic system. Certification and policy rely on developers, yet little focus is given to the sometimes-paradoxical demands developers find themselves amidst when trying to define and pursue sustainable development. The scope of the study has therefor been to acquire and present a developer perspective on sustainable housing. The role of Municipal officials, and the perception of sustainable communities among local politicians, is to be explored further in future research.

A majority of the respondents had direct prior experience within the housing sector, albeit of varying extent in terms of time employed and title previously held. Although the interviews were directed towards representatives from the marketing or development divisions, the flat organizational structure found in smaller companies meant interviews were conducted with higher management or in one case, the CEO (as seen in Table 1). As a result, the respondents held a diverse insight into specific company procedures or policies.

An interview guide was followed containing three main sections (see Table 2). The interview guide was designed to give more or less equal attention to these main sections in order to avoid unilateral focus. The interviewer kept to the interview guide as far as possible, following the same sequence of questions and progression of questions throughout the interviews. However, minor variations naturally 
occurred due to the length and focus of the respective interviewee's response, which will have affected the overall division of time (and words) spent on the different sections [45].

Table 1. List of interviewees.

\begin{tabular}{|c|c|c|c|c|c|}
\hline & Company type & $\begin{array}{l}\text { Number of } \\
\text { employees }\end{array}$ & $\begin{array}{l}\text { Market } \\
\text { range }\end{array}$ & $\begin{array}{c}\text { Type of } \\
\text { apartments } \\
\text { built }\end{array}$ & Interviewee function \\
\hline A & $\begin{array}{l}\text { Construction, forestry } \\
\& \text { property dev.group }\end{array}$ & 900 & National & Tenant-owned & $\begin{array}{l}\text { Project development } \\
\text { manager }\end{array}$ \\
\hline B & $\begin{array}{c}\text { Cooperative real estate } \\
\text { organization }\end{array}$ & 1120 & National & Tenant-owned & $\begin{array}{c}\text { Project \& local market } \\
\text { manager }\end{array}$ \\
\hline $\mathrm{C}$ & $\begin{array}{l}\text { Private real estate } \\
\text { company }\end{array}$ & 180 & National & $\begin{array}{l}\text { Rental \& tenant- } \\
\quad \text { owned }\end{array}$ & Development manager \\
\hline \multirow[t]{2}{*}{$\mathrm{D}$} & $\begin{array}{c}\text { Construction \& } \\
\text { property dev. group }\end{array}$ & 6000 & International & Tenant-owned & Regional manager \\
\hline & $\begin{array}{l}\text { Public housing } \\
\text { company }\end{array}$ & 260 & Local & Rental & $\begin{array}{l}\text { Communication \& } \\
\text { marketing manager }\end{array}$ \\
\hline $\mathrm{F}$ & $\begin{array}{c}\text { Construction \& } \\
\text { property dev. group }\end{array}$ & 17500 & International & Tenant-owned & $\begin{array}{l}\text { Regional manager }+ \\
\text { Marketing manager }\end{array}$ \\
\hline $\mathrm{G}$ & $\begin{array}{c}\text { Private real estate } \\
\text { company }\end{array}$ & 40 & Local/regional & $\begin{array}{l}\text { Rental \& tenant- } \\
\text { owned }\end{array}$ & $\mathrm{CEO}$ \\
\hline
\end{tabular}

Table 2. Interview topics.

\begin{tabular}{lll}
\hline 1. About the company & $\begin{array}{l}\text { 2. Innovation in standards } \& \\
\text { concepts offered }\end{array}$ & $\begin{array}{l}\text { 3. Drivers for housing } \\
\text { development }\end{array}$ \\
\hline 1.1. Type of company & 2.1. Innovation policy & $\begin{array}{l}\text { 3.1. Trends \& Market } \\
\text { 1.2. Market range }\end{array}$ \\
$\begin{array}{l}\text { 2.2. Decision hierarchy } \\
\text { offered }\end{array}$ & $\begin{array}{l}\text { 3.2. Laws, regulation \& policy } \\
\text { 2.3. Alternatives proposed by } \\
\text { the company itself }\end{array}$ \\
\hline
\end{tabular}

The, on average, one hour interviews were recorded in full and transcribed relaying the full content of the interviews. As part of the inductive process the material was then coded using markers on three levels; content relating to the company/industry in general or to Kvillebäcken in specific; content belonging to identified reoccurring main themes of the interview; and content specific to subthemes that might or might not be reoccurring throughout the interviews. The coding was hence done partly with the interview guide in mind, complemented in large by observing the patterns of themes that emerged when reviewing the processed material as a whole.

In order to visualize observed patterns, a text analysis was conducted, according to the themes revealed in the inductive process (see Table 3) [46]. As common in qualitative research, the framing of the interview questions will have affected the choice of wording or focus of the response, which should be considered in the interpretation of the results [47]. The bias emerging from the interviewer's wording and the varying total word usage in each theme was addressed and mitigated by adding the words most frequently used by interviewees as well as interviewer in each theme and subsequently 
comparing the ratio of the words in each theme. To be noted is also that the words "people" and "common" were given extra attention to differentiate usage in a context outside of the thematic group.

Table 3. Words used in thematic analysis, sorted by usage frequency among interviewees from top to bottom (words used in the interview guide in italics).

\begin{tabular}{|c|c|c|c|c|c|}
\hline & Resident & Market & Social Value & Environment & Policy \\
\hline \multirow{10}{*}{ 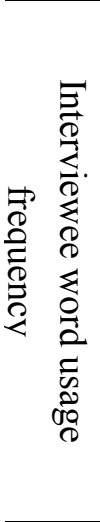 } & People & Market & Common & Energy & Law \\
\hline & Customer & Cost & Quality & Environment & Regulation \\
\hline & Tenant & Companies & Society & Water & Legislation \\
\hline & Resident & Pay & Social & Sustainability & Policy \\
\hline & Inhabitant & Price & Affordable & Electricity & Government \\
\hline & Client & Money & Collective & Heat & Municipality \\
\hline & Consumer & Economic & Affordability & Sustainable & Rules \\
\hline & Dweller & Business & Safety & Waste & Authority \\
\hline & Buyer & Expensive & Security & Efficiency & Tax \\
\hline & & Economy & Collective & & \\
\hline
\end{tabular}

The transcribed material presented here, in the form of anonymized direct quotes as well as general conclusions from the data analysis in its entirety, is used to argue the distinction of a discourse among the developers in the specific case. Particular interviewee's statements are either related to the majority discourse or recounted as expressing a unique minority perspective.

\section{Results}

\subsection{Reported Sustainable Housing Concepts}

Several of the interviewees report that their company tries to implement low-energy or even passive house standards in the housing they build. Several municipalities in the region are working with programs and policies for sustainable urban development, requiring developers to formulate sustainability objectives in order to be offered a plot or given the opportunity to build. The energy requirements in Kvillebäcken are therefore not unfamiliar, although intensified by the combination of several subprojects and initiatives. Some interviewees report particular technical or production-related concepts, often in regards to cost, although overlapping with environmental aspects. One of the interviewees describes the company's focus on wooden constructions, taking a holistic perspective on the process from the forest to the finished housing they offer. Another interviewee further underlines the advantage of developing holistic concepts with an environmental objective: "we started to produce our own energy. So we built windmills across the country actually, and next year we are going to be self-sufficient on all electricity to all our properties, that's nice." The same interviewee stresses that the commitment does not end with renewable energy, but to simultaneously reduce total consumption in the houses they build and manage.

Focus on people and what is perceived as social values or general quality of life for residents is partly discussed, with companies working to improve opportunities for interaction and create greater value for their residents or customers (a distinction should be made between companies building for sale or those building for own property management, where the relationship to the resident as customer 
differs). To describe how these matters of residential quality are regarded, in relation to more technical aspects, one interviewee elaborates: "it's important for us that people think it's nice to live there, and safe to live and so on. So it's more soft kind of issues that are also important."

Commitment to contributing to a larger societal development is acknowledged as a particular explicit motivation for only one of the interviewees; "we try to be a part of the society and contribute to develop the whole society, not the house. We want to be part of building a city." Transparency is however upheld by the municipal public housing company, as well as adhering to a greater social responsibility and engaging with issues on a personal level, beyond the current private company trend: "we were working with CSR before it was invented."

\subsection{Ambitions in Relation to the Market}

Many of the objectives put forward in Kvillebäcken focus on social and economical considerations of for example mixing forms of tenure, creating attractive and vibrant environments that connect to the existing urban structure, as well as the importance of a "social quality of life with security and diversity". The aim is for around $25 \%$ of the 2000 apartments built in Kvillebäcken to be rental units. In the total multi-family housing stock in Sweden, slightly less than $70 \%$ are rental units, a number that is decreasing in favor of an increased share of tenant-owned apartments [48]. Of the seven companies present in Kvillebäcken, one is building solely rental apartments (the municipal housing company), while two others are building apartments of mixed forms of tenure (as seen in Table 1). The majority of the developers are hence building tenant-owned apartments in this particular project, a form of tenure that accounts for about half of the newly built apartments in multi-family housing nationwide [29]. Other alternative forms of tenure are not mentioned.

Housing affordability and the cost of sustainable housing in particular is mentioned by several interviewees, with some noting the increased costs associated with the introduction of new technical or material innovations and practices. Some companies report actively working with reducing end costs for the resident. This is stated in relation to either optimizing the building process and maintenance, or in the case of one of the private real estate companies - eating the costs to be able to "sleep at night" knowing they provide good quality housing they would themselves live in.

However, as building rental dwellings is perceived as economically challenging, this is compensated by the assumption of an urgent housing shortage. One interviewee expounds "as we have a situation in Sweden where the demands for housing in the big cities are so high, the need to be very secure in your surveys is not so important. As long as you build one apartment, you have at least 20-25 persons or families that want to live in that particular apartment." Another respondent admits that "as the market is now, it is not necessary [to stand out], and we will be a little bit lazy. Because we know that we will rent all our apartments anyway, / . ./ I guess, some day it will come, the market /.../ will be satisfied." This pattern is further illustrated in Figure 1, showing that even though environmental and social issues are at the forefront in Kvillebäcken, economical challenges and competition for customers still occupy a relatively large portion of the words spoken in the interviews conducted (accounting also for potential bias in the framing or wording of interview questions).

The potential difference in the commitment of long-term environmental investments between the forms of tenure is further expressed. Companies that build solely for sale are perceived as less 
financially motivated to invest in relationships with residents to get them to keep up the ambitions for the environmental standards in the area, such as practices for recycling or ecological stewardship. Similarly, energy-efficiency measures might be profitable in lowering costs for companies managing the properties as well as residents in all types of dwellings, but has less immediate financial return for those developers leaving the area after it is built and sold. This is an essential aspect of residential development, depending on the dwelling typologies and forms of tenure of apartments built, and the companies building them.

Figure 1. Interviewees' compared with interviewer's usage of words in thematic groups.

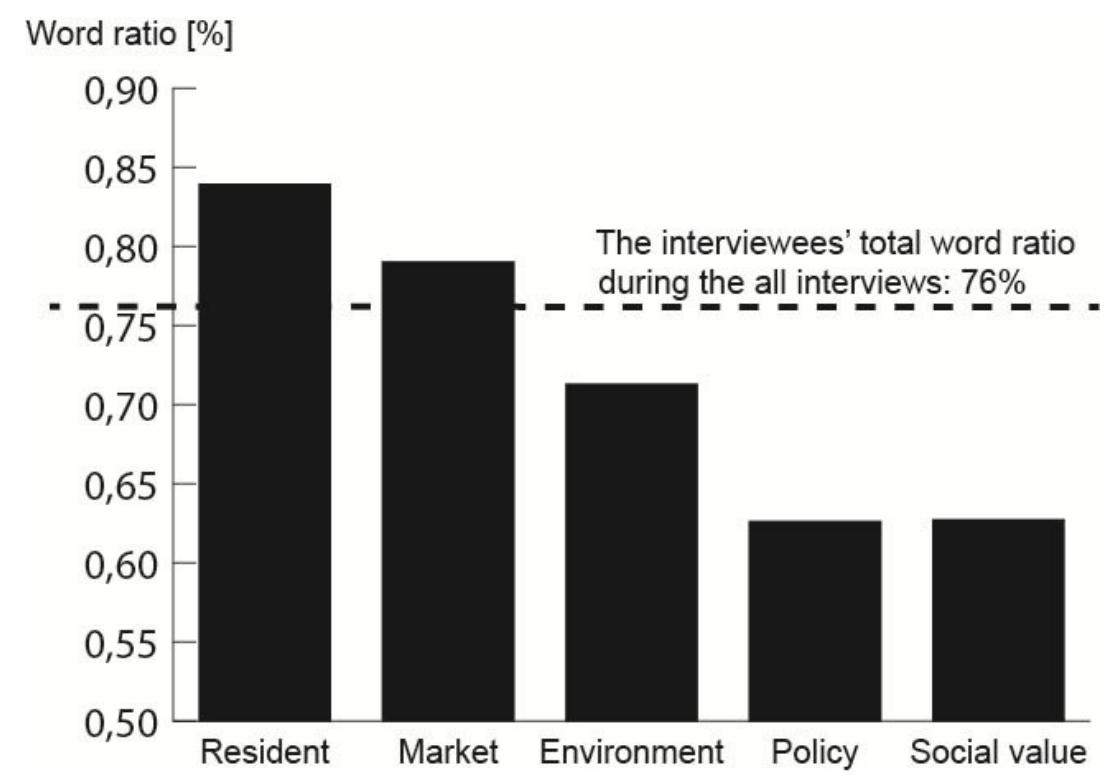

\subsection{Identified Drivers for Development}

\subsubsection{Customers and Market Trends}

Throughout the interviews it can be noted that residents (as tenants or customers) is an important factor to consider within housing development, and is said to be more and more in focus, exemplified by one interviewee; "what we have been discussing a lot lately, is that we have to think more when we build about who we are building for." Another interviewee says; "we have been discussing that we have to think more about the individual customer." Being able to relate to the individual customer is also expressed by another interviewee: "[We have to consider] the situation for the person who is going to live in the flat: how is the living going to be; is it comfortable and good in many ways. We look at the individual, the person, that's important for us." The same interviewee goes on to say that this focus might even be "more important than the building." This is also visualized in the text analysis shown in Table 3, though "people" is the more frequently used word when interviewees are speaking in general terms of public expectations.

Watching what competitors are doing is one way of staying informed on market changes. Knowing and listening to potential customers is however one of the strongest drivers according to the respondents: "We daily observe the trends and market to see what the consumers want to have. In some projects, Kvillebäcken is such a project, we've involved proposed customers in the product 
development phase. It can be done through surveys, forms or interviews in focus groups." Collecting this type of participatory input or feedback is further discussed from the perspective of when in the project it is received. Early interaction might lead to a larger change, whereas less rigorous engagement might result in something of "a little bit cosmetic".

It is proposed that residents are not attracted or interested by innovation per se, but appreciate good quality, comfort, affordability and so on, which might be made possible by new innovations. One interviewee depicts a shift: "you are more demanding as a customer today" and states that "they are picky. Yes, but I mean in a positive way! It is good that they are." That questions of sustainability are becoming increasingly important is concurred among the interviewees, although residents might not be informed about all aspects. This is clarified as when it comes to "these environmental questions, you have to suggest, they don't really know how to demand."

\subsubsection{Laws, Regulations and Policy}

When asked about potential drivers for development of the housing sector, the interviewees proclaim following laws and regulations as ineludible, but in different ways emphasize that this is not necessarily perceived as the sole imperative for pushing new concepts today. One interviewee says; "The regulations and law, you have to take care of that, but then what the customers say, that's the most important I think." Several of the interviewees nevertheless point to laws or national policy regulating contemporary Swedish construction as holding housing development back, correlating an alleged increasing strictness with rising production costs.

The interviews furthermore indicate that especially restrictions aiming to reduce environmental impact are discerned as of growing priority within both local and national government. As more municipalities intensify the demands put on developers wishing to build, companies have to adjust to stay competitive. As previously noted some interviewees highlight that in the case of environmental concerns it is these types of local or national requirements, more than customer interest, that drives the companies' work with these issues; "Sustainability is a very interesting thing to work with, but not so much because the customer wants it, but because the different municipalities demand it from us."

\subsubsection{Developers' Perspectives}

The potential conflicts between different drivers identified in the interviews is commented on by one of the interviewees, who sums the situation up by declaring that: "For us, the developer, it's tough, all these demands from the municipality, and the demands from the customer, and the demands from the market that we should have prices so that everyone can buy these apartments. It's a rather tough equation."

A series of possible other drivers than the ones posed within the structured interview questions are offered. Economy and the current market system is evidently of general concern (as Figure 1 indicates) and is highlighted throughout as an underlying driver for many of the innovations or development of the different concepts the developers work with; "most of the time it is economy that sets the standards." This can be either in the form of keeping costs down for the company, or for the customer-or both.

The companies that particularly work with construction concepts uphold the importance of such focused work to improve building methods or key components to rationalize housing production. 
When asked about ideas within the company that are challenging the common practices within the industry, one interviewee reiterates the choice to focus on a niche within construction; "The biggest thing that you can say goes in opposition to the mainstream is our policy to build with wooden frames in all our projects." Another suggests their company could be said to push housing development by working with industrialized construction, but adds; "I think the whole construction and developer business are like [a school of] fish, mainstream, no one dares to do anything else, I would say."

\section{Discussion}

\subsection{Paradoxes and Possibilities for a Sustainable Housing Sector}

The building sector as a large contributor to the development of productive sectors and regions, but conversely also to the resource depletion and environmental impact of the built environment, needs to conceptualize how this equation is resolved within the claim of building sustainable living environments. The results from the interview study support the contention that there is an imprecision in how such a sustainable development within the housing sector is concretized. Varied interpretations are subsequently made, here presented from a housing developer perspective. The main aspects of this interpretation relate to the assumption of an economical and political system in place; a somewhat restricted perspective on sustainability in housing often limited to "green" solutions. However, the role of the resident in driving development is also emphasized, suggesting a possibility for shifting focus.

The housing sector exemplifies the general paradox of sustaining life support resources while attempting to develop - in the sense of expanding - consumption within the dwelling market. The industry's role in developing equity and equal opportunity and the production of social capital in living environments is in part a question for housing developers and in large relates to the complex processes associated with the creation (or redevelopment) of residential areas.

Beyond the gradually more common technical and quantitative requirements on new residential development, the pursuit of a holistic approach to sustainable housing concepts and the reported engagement with social questions emerge as possibilities for the industry to strengthen the role of informing the discourse on sustainable housing development. However, the case presented here highlights some of the paradoxes with pursuing an interpretation of sustainability in the development of an area such as Kvillebäcken, particularly relating to issues of social mixing and forms of tenure, and the limitations in environmental considerations and focusing on efficiency.

In relation to the existing Swedish housing stock, or even the breakdown of newly built apartments, a ratio of $25 \%$ of the apartments built for renting is below the national average, although remains notable in the context of contemporary central development projects (reflecting also the pressure on urban development and the current housing market system). This could not per se be considered to significantly further an overall societal development towards equal opportunity. Bearing in mind the on average higher monthly rents of new rental apartments, a question is also who will afford to live in such newly developed areas and whether there will be a substantial socio-economic diversity among residents even with a mix in form of tenure, as systemic and social norms foster indebtedness in striving to own one's apartment. 
There is a lack of a holistic alignment of ambitions in this issue, entailing an obstacle for a sustainable housing development, as social and ecological costs of the built environment are not weighted adequately. Although it is recognized that all new construction is high-cost, it is assumed that building "green" is more expensive. A government report commissioned by the Swedish minister of housing to review the obstacles for increased housing production proposes that local energy requirements that go beyond the national guidelines hinders, and thus raises the prize of, construction [49]. Environmental ambitions are thereby put in opposition to overall costs-addressed primarily for developers to stimulate new production (and renovation), as this is further assumed to trickle down to affordability for residents. As with all new innovations in construction, a transition period for knowledge dissemination and competency building within the sector is however necessary, upon which point an assessment of the added costs of green housing construction should be further evaluated. Whether a lowering of requirements would lead to actual lowered housing costs for residents is not conclusive, yet remains a largely uncontested assumption in the political discourse.

The housing shortage especially among rental apartments, as in the Swedish case, further shows a potential obstacle for sustainability in multiple aspects. It speaks against a large investment from the developers in terms of developing social capital or actively working with reducing environmental impact, as the current market situation ensures they will be able to rent out regardless. With minimum norms for spatial and material standard in newly built apartments, the baseline for all new construction still remains high. However, strong local political ambitions for further development are made less prominent in a situation of high demand, considering also the nature of the shortage-rental apartments in urban areas for less affluent groups. The difference in incentives for long-term investments in promoting and upholding sustainable residential practices and social connections with residents between different forms of tenure moreover raises questions of how to overcome obstacles with both tenant-owned and rental apartments for a sustainable housing development.

With municipal and national policy pushing the reduction of particularly energy consumption in new or redeveloped residential areas, the building sector has responded with new products and processes for energy-efficient construction. Policy is however not perceived to be as forceful in clarifying the social dimensions that are required in urban development, making it hard for developers to incorporate these directives. Investing in, and promoting the creation of social capital is not mentioned explicitly in the interviews, but however implied in that relationships with and among residents is something multiple companies work with.

As expressed in the case presented here, the varying demands on and drivers for housing development entail that developers adhere to multiple external policy and customer perspectives as well as position themselves in a competitive market. These oftentimes-conflicting demands pose both obstacles and possibilities for a housing sector that, on top of this, aims to contribute to and take responsibility in an overall sustainable development. In Kvillebäcken, the ambition of the consortium in establishing goals for different sustainability aspects is an attempt to define and concretize these interpretations. The developers' perception of the internal drivers for housing development moreover suggest an obstacle in that the industry after all is competitive, and the possibility to break away from the mainstream is dependent on strong own incentives, supported by a stronger local policy and an interactive customer base. 
Developers report following and wanting to satisfy customers' needs, along with the importance put on residential quality of life. That customers are perceived as becoming more demanding could be seen as a possibility for further challenging and developing the housing offered. However, building for customers' demands is not per se sustainable, as the identified demand and residential lifestyle development might not be in line with an absolute optimization of energy and resource use. From a urban and residential development perspective qualitative, attractive and smart spaces where functions - and therefore also energy and resource use - are shared rather than individualized present themselves as necessary to challenge the trend of improved spatial and material standards and the increase in single households. Ensuring an equitable development, where diverse residents are given space and access to influence their living environments, is not a simple task. Especially for developers operating within a market where specifying target groups is an efficient strategy to be able to focus on and offer residential quality as defined in relation to that particular context.

\subsection{Ways Forward}

Conceptualizing and attempting to concretize what a sustainable housing development entails emphasizes the role of the housing sector in informing the discourse on the development of holistically sustainable living environments, beyond the representation of "sustainable housing". A market perspective on speculative residential construction supposes and results in one type of sub-optimized interpretation of development [50].

In order to avoid paradoxical discourses and sub-optimal progress in the building sector, a holistic perspective on sustainable development including dimensions of social capital and equal opportunities linked with an ecological modernization perspective is needed. This holistic perspective must also entail a systems thinking on multiple levels to take rebound effects and individuals' opportunities for engagement and prioritizations into account. Socio-cultural aspects of the built environment, along with affordability, remain important issues to be incorporated.

A clarification and strengthening of policy is essential, yet continues to be regarded as problematic in a market-environmentalist paradigm. There is nonetheless a need for an alignment between how industry, policy and the market perceive housing development and what is actually sustainable. This goes beyond the contemporary discourse on efficiency — what and how to sustain - and the current social target groups-for whom and what to develop. Such a discourse would move focus from efficiency to sufficiency. By making this shift it is possible to more adequately reach equal opportunity targets on a local scale and address issues of housing affordability in relation to local prerequisites, beyond standard definitions [30].

To provide possibilities to move beyond, the industry can recognize new forms of development. An example is smaller developers with a more local rootedness, which could not only diversify the built environment but also recognize the value in building social capital and long-term economic and social resilience. Opportunities to build homes that increase social capital, while not contributing to increased consumption within the dwelling market, lie in local engagement [38], a sense of "at-homeness", diversifications of existing social structures [51], and collective resource use as opposed to individualized. An important policy tool in reaching the inhabitants is the tenure type and financing mechanisms promoted. Alternative tenure and financing structures can be used to support resource 
efficient living, stimulate local engagement and encourage possibilities for social development. One such tenure type is provided in for example cooperative rental organizations. Building varied apartments and facilitating downgrading/upgrading of living space within the organization, building or residential area would further increase the resilience of the area and build social capital.

Although the presented findings refer to a Swedish context, the issues raised can be found in similar urban cases in metropolitan growth regions around Europe and additional comparative studies should be made with international studies. Attention should also be given to mapping the perspective among other actors in housing development, such as policy makers, local officials, builders, facilities managers and end-users as citizens and residents.

\section{Conclusions}

The range and vagueness in demands in which the housing sector operates contributes to a restricted and unilateral interpretation of sustainability. Lacking a clear general conceptualization, policy formulation within national or local government, as well as within the housing development sector, consequently presents a challenge for implementation of sustainable practices and strategies.

There is for example a direct inconsistency of sustaining life support resources while developing consumption if developing is synonymous with increasing. In the housing sector, this paradox is illustrated in the dependency of a growing market and speculation while working with increasing residential quality, social values and equal opportunities. This is supported by the results from the presented interview study in the case of a "green" residential development. The assumption of a current market structure, along with a limited focus on sustainability, is highlighted, but so is also the role of the resident. Possibilities for the housing sector are given in the recognition of new forms of development, where the creation of social capital and resident engagement is upheld.

The presented material illustrates a national (through a Swedish case), as well as European or global issue. In summary, it is argued that the market on its own is not delivering holistically sustainable living environments, but rather work from an interpretation of sustainability with a limited reach. Instead, local and personal responsibility and initiatives taken within the housing sector can be found to have greater impact on the development of sustainable housing. Developing both policy and practice, as well as emphasizing collaboration for a more holistic discourse, is proposed.

In order to achieve the large-scale impact needed to create more sustainable living environments, an adaptation of multi-level changes through systemic thinking and a holistic perspective is required. This goes beyond the discourse on technical solutions and the superficial understanding of social development, moving focus from efficiency to sufficiency. This holistic perspective must entail various levels, and social dimensions incorporated into the ecological modernization paradigm.

\section{Acknowledgments}

The study presented is part of ongoing research work funded by the Swedish Research Council Formas, within the strong research environment "Homes for Tomorrow" at Chalmers University of Technology. The authors would finally like to thank Guillemette Zuber for her excellent work with preparation and data collection. 


\section{Conflict of Interest}

The authors declare no conflict of interest.

\section{References}

1. Spence, R.; Mulligan, H. Sustainable development and the construction industry. Habitat Int. 1995, 19, 279-292.

2. Sev, A. How can the construction industry contribute to sustainable development? A conceptual framework. Sustain. Dev. 2009, 17, 161-173.

3. Jensen, J.O.; Jørgensen, M.S.; Elle, M.; Lauridsen, E.H. Has social sustainability left the building? The recent conceptualization of "sustainability" in Danish buildings. Sustain. Sci. Pract. Pol. 2012, 8, 94-105.

4. Maliene, V.; Howe, J.; Malys, N. Sustainable Communities: Affordable Housing and Socio-economic Relations. Local Econ. 2008, 23, 267-276.

5. Priemus, H. How to make housing sustainable? The Dutch experience. Environ. Plann. Plann. Des. 2005, 32, 5-19.

6. Raco, M. A growth agenda without growth: English spatial policy, sustainable communities, and the death of the neo-liberal project? GeoJournal 2012, 77, 153-165.

7. Winston, N. Regeneration for sustainable communities? Barriers to implementing sustainable housing in urban areas. Sustain. Dev. 2010, 18, 319-330.

8. Crabtree, L. Sustainable Housing Development in Urban Australia: exploring obstacles to and opportunities for ecocity efforts. Aust. Geogr. 2005, 36, 333-350.

9. Xue, J. Limits to decoupling strategies for sustainable housing development: The Hangzhou experience. J. Environ. Plann. Man. 2012, 55, 1004-1021.

10. Lorenz, D.; Lützkendorf, T. Sustainability in property valuation: theory and practice. J. Property Invest. Finance 2008, 26, 482-521.

11. Malmqvist, T.; Glaumann, M.; Scarpellini, S.; Zabalza, I.; Aranda, A.; Llera, E.; Díaz, S. Life cycle assessment in buildings: The ENSLIC simplified method and guidelines. Energy 2011, 36, 1900-1907.

12. Anderssen, I.; Thomsen, K.E.; Wahlstrøm, Å. Nordic Analyses of Climate Friendly Buildings. Available online: http://www.nordicinnovation.org/Global/_Publications/Reports/2010/Nordic\% 20Analysis\%20of\%20Climate\%20Friendly\%20Buildings.pdf (accessed on 18 April 2013).

13. Femenías, P.; Kadefors, A. Clients' strategies for driving innovation in low energy building. Paper presented at the Sustainable Building Conference, Helsinki, Finland, October 2011. Available online: http://publications.lib.chalmers.se/records/fulltext/local_145376.pdf (accessed on 18 April 2013).

14. Zhang, X.; Shen, L.; Wu, Y. Green strategy for gaining competitive advantage in housing development: a China study. J. Clean. Prod. 2011, 19, 157-167.

15. Schweber, L.; Leiringer, R. Beyond the technical: a snapshot of energy and buildings research. Build. Res. Inform. 2012, 40, 481-492. 
16. Lovell, H. Framing sustainable housing as a solution to climate change. J. Environ. Pol. Plann. 2004, 6, 35-55.

17. Luke, T.W. Neither sustainable nor development: reconsidering sustainability in development. Sustain. Dev. 2005, 13, 228-238.

18. Verbruggen, H. Dual goal: Economic growth along with environmental improvement. Stud. Environ. Sci. 1998, 72, 961-968.

19. Turner, G.M. A comparison of The Limits to Growth with 30 years of reality. Global Environ. Change 2008, 18, 397-411.

20. Mol, A.P.J.; Sonnenfeld, D.A.; Spaargaren, G. The Ecological Modernisation Reader: Environmental Reform in Theory and Practice; Routledge: London, UK, 2009.

21. Jensen, J.O.; Gram-Hanssen, K. Ecological modernization of sustainable buildings: A Danish perspective. Build. Res. Inform. 2008, 36, 146-158.

22. Wijkman, A.; Rockström, J. Bankrupting Nature: Denying Our Planetary Boundaries; Routledge: New York, NY, USA, 2012.

23. Stoddart, H.; Riddlestone, S.; Vilela, M. Principles for the Green Economy. A collection of principles for the green economy in the context of sustainable development and poverty eradication. Available online: http:/www.stakeholderforum.org/fileadmin/files/Principles\% 20FINAL\%20updated.pdf (accessed on 1 February 2013).

24. Kates, R.W.; Parris, T.M.; Leiserowitz, A.A. What is Sustainable Development? Environment 2005, 47, 8-21.

25. Huesemann, M.H.; Huesemann, J.A. Will progress in science and technology avert or accelerate global collapse? A critical analysis and policy recommendations. Environ. Dev. Sustain. 2008, 10, 787-825.

26. Agnello, L.; Schuknecht, L. Booms and busts in housing markets: determinants and implications. J. Hous. Econ. 2005, 20, 171-190.

27. Rybkowska, A.; Schneider, M. Housing Conditions in Europe in 2009. http://www.epp.eurostat.ec. europa.eu/cache/ITY_OFFPUB/KS-SF-11-004/EN/KS-SF-11-004-EN.PDF (accessed on 1 February 2013).

28. Bostadsmarknaderna i Norden och regionalt; Boverket: Karlskrona, Sweden, 2010.

29. SCB. Yearbook of Housing and Building Statistics 2012; SCB-Tryck: Örebro, Sweden, 2012.

30. Mulliner, E.; Smallbone, K.; Maliene, V. An assessment of sustainable housing affordability using a multiple criteria decision making method. Omega 2013, 41, 270-279.

31. Beer, A.; Kearins, B.; Pieters, H. Housing Affordability and Planning in Australia: The Challenge of Policy Under Neo-liberalism. Housing Stud. 2007, 22, 11-24.

32. Choguill, C.L. The search for policies to support sustainable housing. Habitat Int. 2007, 31, 143-149.

33. Turner, B.; Whitehead, C.M.E. Reducing Housing Subsidy: Swedish Housing Policy in an International Context. Urban Stud. 2002, 39, 201-217.

34. Brown, T.; Bhatti, M. Whatever Happened to 'Housing and the Environment'? Housing Stud. 2003, 18, 505-515.

35. Hoffman, A.J.; Henn, R. Overcoming the Social and Psychological Barriers to Green Building. Organ. Environ. 2008, 21, 390-419.

36. Spaargaren, G. Ecological modernization theory and domestic consumption. J. Environ. Pol. Plann. 2000, 2, 323-335. 
37. Hille, J.; Simonsen, M.; Aall, C. Trender og Drivere for Energibruk i Norske Husholdninger. Rapport til NVE; Vestlandsforsking: Sogndal, Norway, 2011.

38. Strengers, Y. Bridging the divide between resource management and everyday life-Smart metering, comfort and cleanliness. Ph.D. Thesis, RMIT University, Melbourne, Australia, 2009.

39. Falkheden, L. Local area as a strategy for sustainable urban development. Case studies of three Danish examples. Ph.D Thesis, Chalmers University of Technology, Göteborg, Sweden, 1999.

40. The Kvillebäcken Consortium. Program för Hållbar utveckling $i$ Kvillebäcken. Available online: http://kvillebacken.se/upload/Program-for-utveckling-Kvillebacken_110927.pdf (accessed on 16 July 2012).

41. Ragin, C.C.; Becker, H.S. What is a Case?: Exploring the Foundations of Social Inquiry; Cambridge University Press: New York, NY, USA, 1992.

42. Yin, R.K. Case Study Research: Design and Methods; Sage Publications: London, UK, 2008.

43. Esaiasson, P.; Gilljam, M.; Oscarsson, H.; Wängnerud, L. Metodpraktikan; Nordsteds Juridik: Stockholm, Sweden, 2007.

44. Van den Bergh, J.C.J.M. Environment versus growth-A criticism of "degrowth" and a plea for “a-growth". Ecol. Econ. 2011, 70, 881-890.

45. Kvale, S.; Brinkmann, S. Interviews: Learning the craft of qualitative research interviewing; Sage Publications: London, UK, 2008.

46. Thompson, I. Collaboration in technical communication: a qualitative content analysis of journal articles, 1990-1999. IEEE T. Prof. Commun. 2001, 44, 161-173.

47. Alvesson, M.; Sköldberg, K. Reflexive methodology: New vistas for qualitative research; Sage Publications: London, UK, 2009.

48. Bostadsmarknaden 2008-2009-med slutsatser av bostadsmarknadsenkäten 2008; Boverket: Karlskrona, Sweden, 2008.

49. Hedlund, B. Ökat bostadsbyggande och samordnade miljökrav-genom enhetliga och förutsägbara byggregler; SOU 2012:86: Stockholm, Sweden, 2012.

50. Moore, S.; Bunce, S. Delivering sustainable buildings and communities: eclipsing social concerns through private sector-led urban regeneration and development. Local Environment 2009, 14, 601-606.

51. Schroepfer, T.; Hee, L. Emerging Forms of Sustainable Urbanism: Case Studies of Vauban Freiburg and solarCity Linz. J. Green Build. 2008, 3, 65-76.

(C) 2013 by the authors; licensee MDPI, Basel, Switzerland. This article is an open access article distributed under the terms and conditions of the Creative Commons Attribution license (http://creativecommons.org/licenses/by/3.0/). 